\title{
Wirtualne laboratorium w nauczaniu podstaw psychologii behawioralnej
}

\begin{abstract}
The description and explanation of human behavior in behavioral psychology is conducted according to nonhuman animal model. This field of science is based on primary learning processes such as classical and operant conditioning, which were discovered due to research on animals. Therefore, many U.S. colleges and universities use animal laboratory experiments in teaching undergraduate and graduate courses of psychology. Decreasing public support for research on live animals, more strict regulations in animal laws and high laboratory maintaining costs caused that alternative ways to demonstrate students the rights of learning and shaping behavior were looked for. Due to the expand of personal computers, programs and virtual models simulating live animals behavior were developed. The most popular one and currently most accessible is „Sniffy, the virtual rat”. The paper discusses the possibility of using the program in teaching. Moreover, the results of two surveys on using live versus virtual animals in didactics of behavioral psychology, carried out among students, are presented and discussed.
\end{abstract}

\section{Keywords:}

behavioral psychology, behavior analysis, classical conditioning, operant conditioning, virtual animal lab, Sniffy the Virtual Rat

${ }^{1}$ Szymon Breński, Instytut Psychologii, Wydział Nauk Społecznych, Uniwersytet im. Adama Mickiewicza w Poznaniu, Polska, bresz@amu.edu.pl. 


\section{WPROWADZENIE}

Behawioryzm, zarówno w swej historycznej, jak i współczesnej postaci, wyjaśnia zachowanie człowieka działaniem czynników zewnętrznych, odwołując się przy tym do elementarnych procesów uczenia się: warunkowania klasycznego oraz warunkowania sprawczego. Mimo że, podstawowe badania nad uczeniem się zostały przeprowadzone pod koniec XIX i w pierwszej połowie XX wieku, prawa kształtowania zachowania sformułowane na ich podstawie nie straciły na aktualności. Jednak odwoływanie się do nich dla wielu osób wydaje się anachronizmem, gdyż dość powszechne jest traktowanie behawioryzmu jako ważnego kierunku teoretycznego na drodze rozwoju psychologii, jednak dziś już nieaktualnego i mającego wartość jedynie historyczną (Bąbel, Ostaszewski, 2008; Paw, 2010).

Przekonanie, że psychologia behawioralna należy do historii, może powodować bagatelizowanie osiągnięć nauki o zachowaniu. Rodzi to nieporozumienia i prowadzi do nagromadzenia licznych mitów (por. Bąbel, Suchowierska-Stephany, Ostaszewski, 2016). Taki stan rzeczy stawia wyzwanie przed dydaktykami, w jaki sposób przekazać studentom wiedzę o procesach uczenia się i podstawach psychologii behawioralnej. Chodzi nie tylko o to, aby adepci psychologii przestali traktować behawioryzm jak ciekawostkę z dziejów myśli psychologicznej, lecz by dostrzegli w procesach warunkowania ważne kategorie pojęciowe skutecznie służące do opisu i wyjaśniania zachowania.

\section{2. ŹRÓDŁA PSYCHOLOGII BEHAWIORALNEJ}

Dawniej mawiano ponoć, że ustalenia psychologii w 95\% odnoszą się do szczurów, a w pozostałych 5\% do studentów psychologii (Domachowski, 2007). Choć jest w tym stwierdzeniu dużo przesady, to jednak dość trafnie oddaje fundamentalną rolę, jaką obserwacja funkcjonowania zwierząt odegrała w formułowaniu praw zachowania. To właśnie badania nad zwierzętami doprowadziły do odkrycia dwóch elementarnych procesów uczenia się: warunkowania klasycznego (classical conditioning) i sprawczego (operant conditioning), które legły u podstaw psychologii behawioralnej.

J.B. Watson formułując w 1913 roku swój program behawioryzmu postulował, aby psychologia była „w pełni obiektywną, eksperymentalną dziedziną nauk przyrodniczych”. Uważał, że należy porzucić pojęcia mentalistyczne, a przedmiotem psychologii uczynić to, co zewnętrznie obserwowalne i poddające się obiektywnym procedurom eksperymentalnym, czyli zachowanie człowieka. 
Pozbywając się terminów mentalistycznych, za adekwatne do opisu zachowania Watson uznał pojęcia: bodziec, reakcja, nawyk (Watson, 1990/1925, s. 422). Inspiracją dla Watsona były badania nad odruchami warunkowymi prowadzone przez Pawłowa oraz Biechtieriewa (Watson, 1916; Hergenhahn, 2009). Ujęcie zachowania w kategoriach reakcji odruchowych pozwalało na uniknięcie odwołań do świadomości. Chcąc przewidywać i kontrolować zachowanie człowieka - a taki cel postawił przed psychologią „pierwszy behawiorysta” - konieczna jest znajomość tego, co powoduje zmiany w zachowaniu i tworzenie się nawyków. Watson miał nadzieję, że w przyszłości będzie możliwe przewidywanie reakcji na podstawie znajomości bodźców oraz odkrywanie bodźców dzięki znajomości reakcji. Jego propozycja była więc psychologią bodźca-reakcji (S-R) bez uwzględniania pośredniczących w tej relacji procesów wewnętrznych (Bąbel, Ostaszewski, 2008).

Radykalny behawioryzm w wydaniu B.F. Skinnera poszedł jeszcze dalej. Skinner uważał nie tylko, że przedmiotem psychologii powinno być zachowanie człowieka, ale że w kategoriach zachowania rozpatrywać można myśli i emocje, które podlegają tym samym prawom, co czynności fizyczne. Według niego zdarzenia publiczne (zachowanie dostępne obserwacji innych osób) oraz zdarzenia prywatne (myśli i uczucia dostępne jedynie osobie je przeżywającej) „mają te same rodzaje fizycznych charakterystyk" (Skinner, 2000/1963, s. 92). To założenie o jednolitości zachowań publicznych i prywatnych prowadzi do stanowiska, według którego zachowań wewnętrznych (myśli i uczuć) nie można traktować jako przyczyny zachowań zewnętrznych, gdyż jedne i drugie zachowania wymagają wyjaśnień w tych samych kategoriach przyczynowo-skutkowych (Bąbel, Ostaszewski, 2008).

Stając się swoistą filozofią nauki, radykalny behawioryzm legł u podstaw analizy zachowania - głównego nurtu współczesnej psychologii behawioralnej (Bąbel, Suchowierska-Stephany, Ostaszewski, 2016). W przeciwieństwie do klasycznego behawioryzmu, który traktował zachowanie człowieka jako reaktywne, Skinner zainteresował się zachowaniami spontanicznymi. Zachowania swobodnie emitowane przez organizm, nazywane przez niego sprawczymi, wywołują w otoczeniu określone konsekwencje, co z kolei wpływa na prawdopodobieństwo ponownego wystąpienia tych zachowań. Jeśli dana aktywność przynosi pożądany skutek, wzrasta prawdopodobieństwo jej ponownego wystąpienia. Analogicznie, jeśli skutek zachowania jest niepożądany, organizm zaprzestaje jego emisji (Bąbel, Suchowierska-Stephany, Ostaszewski, 2016). Są to podstawowe zasady procesu uczenia się nazywanego warunkowaniem sprawczym, które stanowiło punkt centralny badań Skinnera nad zachowaniem i czynnikami je kształtującymi. Teoretyczne zaplecze analizy zachowania odwołuje się głównie do wyników 
badań nad warunkowaniem sprawczym, co nie zmienia faktu, że mechanizmy warunkowania klasycznego wciąż są ważnym punktem odniesienia (por. Bąbel, Suchowierska-Stephany, Ostaszewski, 2016).

\section{NAUCZANIE PSYCHOLOGII BEHAWIORALNEJ}

Watson uważał, że psychologia naukowa powinna traktować człowieka tak jak inne zwierzęta, stosując tego samego rodzaju procedury i język opisu (Watson, 1990/1925). Współcześnie celem analizy zachowania jest również poszukiwanie „uniwersalnych (ponadgatunkowych) praw i prawidłowości, opisujących relację między środowiskowymi zmiennymi niezależnymi a zachowaniem, traktowanym jako zmienna zależna” (Bąbel, Ostaszewski, 2008, s. 9). Można zatem powiedzieć, że psychologia behawioralna przyjmuje zwierzęcy model ludzkiego zachowania. Pomimo zarzutów o redukcjonizm, jego istotną zaletą jest to, że podobnie jak inne proste modele złożonych układów pozwala na badanie pewnych aspektów tych układów w warunkach, które są prostsze, tańsze i podlegające większej kontroli (Domjan, 2015). Ma to swoje przełożenie nie tylko na metodologię analizy zachowania, ale również na sposób, w jaki się jej naucza.

W 1948 roku psychologowie z Uniwersytetu Columbia opisali aparaturę laboratoryjną, którą wykorzystywali w prowadzeniu kursu wprowadzającego do psychologii eksperymentalnej (Frick, Schoenfeld, Keller, 1948). Sprzęt do ćwiczeń przypominał standardową „klatkę Skinnera” (operant chamber) i umożliwiał administrowanie wzmocnieniami (pokarm) i karami (szok elektryczny) oraz rejestrowanie reakcji szczura. Dzięki temu studenci mogli w praktyce poznać generalne zasady leżące u podstaw zachowania, wcześniej omawiane jedynie na wykładach (Frick, Schoenfeld, Keller, 1948).

Od czasu tej publikacji standardem na wielu uczelniach amerykańskich stało się wyposażanie laboratoriów psychologicznych w aparaturę dydaktyczną umożliwiającą przeprowadzanie eksperymentów nad uczeniem się zwierząt (Godcharles, Stebbins, 1962; Domjan, Purdy, 1995). Według Karpa (1995, s. 147) takie zajęcia pozwalają studentom nie tylko wyuczyć się na pamięć pojęć psychologicznych, ale także doświadczyć ich „w akcji”, a co za tym idzie - uwierzyć w ich trafność. Uważa on także, że poza oczywistymi korzyściami poznawczymi związanymi ze zdobyciem wiedzy zajęcia takie rozwijają ważne umiejętności kliniczne i interpersonalne.

Ankieta przeprowadzona przez Cunninghama w 2001 roku pokazała, że wykorzystywanie zwierząt (w większości szczurów - 81\% i innych gryzoni - 26\% oraz 
ptaków - 28\%) w celach dydaktycznych na kierunku psychologia i pokrewnych jest dość powszechną praktyką na uczelniach amerykańskich (Cunningham, 2003). Spośród 262 najlepszych szkół wyższych w USA i Kanadzie, które brały udział w badaniu, $62 \%$ oferuje zajęcia oparte na doświadczeniach ze zwierzętami. Równie powszechne jest poparcie dla wykorzystywania zwierząt w nauce i edukacji. W ankiecie przeprowadzonej w 1994 roku wśród członków Amerykańskiego Towarzystwa Psychologicznego 80\% respondentów opowiedziało się za wykorzystywaniem zwierząt dla celów naukowych, a prawie $60 \%$ respondentów wyraziło poparcie dla wykorzystania zwierząt na potrzeby dydaktyki (Plous, 1996). Jednocześnie odpowiednio 14\% i 26\% uczestników badania opowiedziało się przeciwko przeprowadzaniu na zwierzętach doświadczeń naukowych oraz wykorzystywaniu ich w celach dydaktycznych. Z jeszcze większym sprzeciwem spotyka się stosowanie procedur, które są przyczyną cierpienia lub śmierci zwierząt. Na takie praktyki nie zgadza się od ok. 45\% (kiedy badania dotyczą gołębi i szczurów) do ponad 60\% (kiedy badania dotyczą naczelnych i psów) ankietowanych psychologów (Plous, 1996). Plous zauważa tutaj wyraźną zmianę pokoleniową (związaną również ze wzrastającym odsetkiem kobiet wśród psychologów), polegającą na mniejszej akceptacji wśród młodszej generacji psychologów dla badań z udziałem zwierząt i większym poparciu dla prawnych regulacji tej kwestii (Plous, 1996). Trend ten obejmuje również studentów, którzy coraz częściej odmawiają przeprowadzania doświadczeń na zwierzętach lub domagają się zaoferowania alternatywnej formy zajęć (por. Cunningham, 2000).

W ankiecie przeprowadzonej przez Cunninghama (2003) ponad 70\% uczelni zgłosiło stosowanie alternatywnych pomocy dydaktycznych w postaci interaktywnych komputerowych symulacji, informacji ze źródeł internetowych, materiałów audio-wizualnych oraz ćwiczeń przeprowadzanych przez studentów na samych sobie. Największą popularnością cieszą się komputerowe symulacje, które w sposób najbardziej zbliżony do rzeczywistych eksperymentów oddają zasady pracy nad warunkowaniem reakcji u zwierząt. W ostatniej dekadzie XX wieku, wraz z upowszechnieniem komputerów osobistych powstało przynajmniej kilka programów komputerowych w postaci „wirtualnych laboratoriów”, które były testowane przez dydaktyków jako możliwa alternatywa dla doświadczeń na żywych zwierzętach (por. Graf, 1995; Murphy, Madigan, 2011; Alloway, Wilson, Graham, 2012). Spośród nich wciąż aktualizowany i powszechnie dostępny na rynku jest jedynie program „Sniffy, the virtual rat”, który w czasie rzeczywistym symuluje zachowania szczura, przypominając przy tym grę komputerową.

Efektywność programu Sniffy w dydaktyce testowały Venneman i Knowles (2005), które sprawdzały, w jaki sposób wykonywanie przez studentów symulacji 
warunkowania sprawczego przy różnych rozkładach wzmocnień wpłynie na wynik końcowy egzaminu. Okazało się, że grupa eksperymentalna przygotowująca się do zaliczenia wykonując symulacje doświadczeń miała istotnie wyższe wyniki (średnio o całą ocenę) od dwóch grup kontrolnych. Dane na temat preferencji studentów względem programu Sniffy przedstawiają Elcoro i Trundle (2013). Zorganizowały one grupę zajęciową, której uczestnicy mieli możliwość pracować zarówno z żywym, jak i wirtualnym szczurem, ucząc się zasad warunkowania sprawczego. Na podstawie ankiety zebranej po zajęciach badaczki stwierdziły, że studenci wolą pracę z żywymi zwierzętami, traktując ją jako bardzo interesującą i dającą okazję do zdobycia doświadczenia w praktycznych badaniach (hands-on research). Wśród wad komputerowej symulacji wymienione zostały m.in. brak obserwacji rzeczywistego zachowania, nuda czy powtarzalność. Zauważoną przez studentów zaletą jest to, że program umożliwia przeprowadzanie doświadczeń przez osoby, które boją się gryzoni. Ponadto wirtualny szczur jest tańszy i „,czystszy” w obsłudze (Elcoro, Trundle, 2013).

Autorzy programu jako ważną zaletę podają etyczny wymiar stosowania symulacji zamiast żywego zwierzęcia (Alloway, Wilson, Graham, 2012). Jest to szczególnie istotne w warunkowaniu klasycznym, które w przypadku uczenia zwierzęcia warunkowej reakcji emocjonalnej wiąże się z zadawaniem mu wstrząsów elektrycznych. Kompromisowym rozwiązaniem zastosowanym przez Murphyego i Madigana (2011) jest wykorzystanie wirtualnej symulacji na zajęciach poświęconych warunkowaniu klasycznemu oraz żywych zwierząt do demonstrowania praw warunkowania sprawczego. Na takie rozwiązanie mogą pozwolić sobie szkoły wyższe, które dysponują odpowiednim laboratorium. W przypadku uczelni, które nie mają dostępu do zwierząt doświadczalnych, wykorzystanie programu Sniffy - poza fotografiami i materiałami audio-wideo - może być jedyną okazją do zademonstrowania, jak przebiegają eksperymenty nad uczeniem się (Venneman, Knowles, 2005). Warto dodać, że 100 spośród 262 ankietowanych przez Cunninghama (2003) uczelni w ogóle nie oferowało studentom psychologii możliwości przeprowadzania doświadczeń na zwierzętach, ale aż 76 spośród nich wykorzystywało jakieś alternatywne pomoce dydaktyczne.

\section{DYDAKTYKA PSYCHOLOGII BEHAWIORALNEJ W POLSCE}

Choć klasyczne prace behawiorystów są znane w Polsce od dawna, analiza zachowania jako obszar badań, praktyki i nauczania w ramach psychologii ma stosunkowo krótką historię. Początki zainteresowania analizą zachowania w Polsce sięgają 
ostatniej dekady XX wieku i wiążą się z ośrodkami uniwersyteckimi w Warszawie, Krakowie i Gdańsku (por. Bąbel, Suchowierska-Stephany, Ostaszewski, 2016). Psychologowie zaszczepiający to podejście na rodzimym gruncie nie tylko wykorzystywali je do rozwiązywania problemów badawczych i praktycznych, ale również przygotowali interesującą ofertę dydaktyczną dla studentów. Aktualnie zajęcia szczegółowo omawiające zagadnienia analizy zachowania prowadzone są na Uniwersytecie Jagiellońskim, Uniwersytecie Warszawskim oraz SWPS Uniwersytecie Społecznohumanistycznym (Bąbel, Suchowierska-Stephany, Ostaszewski, 2016). Zajęcia te w większości odbywają się w formie fakultetów lub studiów podyplomowych, krąg słuchaczy jest więc mocno ograniczony.

Zdecydowana większość studentów poznaje paradygmat behawiorystyczny w sposób bardzo ogólny, przez pryzmat narosłych stereotypów, a w efekcie traktuje go jako nieaktualny nurt psychologii (por. Bąbel, Ostaszewski, 2008; Paw, 2010; Bąbel, Suchowierska-Stephany, Ostaszewski, 2016). Tę obserwację potwierdza analiza programów kształcenia w bloku podstawowym na kierunku psychologia, zawartych w książce Standardy kształcenia psychologów (Brzezińska, Brzeziński, Eliasz, 2000). Najwięcej bezpośrednich odwołań do psychologii behawioralnej znajduje się w sylabusach do zajęć wprowadzających oraz opisujących historię myśli psychologicznej, co sprzyja wrażeniu o jedynie historycznej wartości tego paradygmatu. Wrażenie to podtrzymuje proponowana literatura do zajęć, obejmująca klasyczne teksty behawiorystów, które nie oddają aktualnego stanu wiedzy o analizie zachowania. Ponadto podręczniki do psychologii ogólnej i wprowadzenia do psychologii proponowane w sylabusach zazwyczaj przedstawiają badania paradygmatu behawiorystycznego w sposób pobieżny i nierzetelny, co negatywnie wpływa na przekonania, jakie studenci tworzą na jego temat (Domjan, Purdy, 1995).

Obok problemu przekazywanych na studiach treści dotyczących psychologii behawioralnej istotny jest też sposób ich prezentacji. Nawet rzetelne informacje, podane jedynie w formie wykładu lub lektury podręcznika, łatwo zostaną zapomniane. Ze względu na pożądane efekty edukacyjne aktualny jest więc postulat kładzenia większego nacisku na demonstrację praktycznego oblicza analizy zachowania i organizację zajęć o charakterze ćwiczeniowym i laboratoryjnym. Dlatego pytanie o zakres wykorzystania zwierząt w nauce to również pytanie o to, czy można zrezygnować z tak wartościowego sposobu zdobywania wiedzy, jakim są wykonywane przez studentów doświadczenia na zwierzętach (por. Karp, 1995). W związku z tym, że w polskiej psychologii brak jest silnej tradycji prowadzenia badań na zwierzętach (z wyjątkiem ośrodka warszawskiego, por. Bąbel, Suchowierska-Stephany, Ostaszewski, 2016), a tym bardziej wyko- 
rzystania doświadczeń na zwierzętach w edukacji, istotne jest zastanowienie się, jakie alternatywne metody dydaktyczne warto stosować. Przykład popularności, jaką cieszy się na studiach psychologicznych podręcznik Psychologia poznawcza (Nęcka, Orzechowski, Szymura, 2006) i załączona do niego płyta CD z eksperymentami i demonstracjami do wykorzystania na zajęciach, sugeruje, że warto poszukiwać podobnych rozwiązań. Na gruncie psychologii behawioralnej szeroko dostępnym rozwiązaniem jest program „Sniffy, the virtual rat”. Chociaż dla studentów nie jest on tak atrakcyjny jak praca z żywym zwierzęciem (Elcoro, Trundle, 2013), to przez wykładowców uznawany jest za efektywną pomoc dydaktyczną (Venneman, Knowles, 2005; Jakubow, 2007). Warto zastanowić się więc, czy program ten może zainteresować studentów psychologii w Polsce oraz jakie walory przemawiałyby za jego wykorzystaniem na zajęciach. W celu odpowiedzi na te pytania, w dalszej części artykułu prezentowane są wyniki dwóch ankiet przeprowadzonych wśród studentów psychologii Uniwersytetu im. Adama Mickiewicza w Poznaniu.

\section{Ankieta nr 1: Zainteresowanie psychologią behawioralną oraz praca z wirtualnym szczurem}

Celem przeprowadzonej ankiety było sprawdzenie, jak studenci, którzy zrealizowali większą część podstawowego bloku zajęć na studiach psychologicznych, odnoszą się do możliwości poszerzenia swojej wiedzy z zakresu psychologii behawioralnej.

\section{METODA}

\section{Uczestnicy}

Ankieta została przeprowadzona wśród studentów kończących II i III rok psychologii (tryb stacjonarny) na Uniwersytecie im. Adama Mickiewicza w Poznaniu. Osoby te zrealizowały już większość przedmiotów z bloku podstawowego i stoją przed wyborem różnych zajęć fakultatywnych. Do wszystkich studentów (ok. 200 osób na każdym roku) na uczelnianą skrzynkę pocztową została wysłana wiadomość elektroniczna z prośbą o wzięcie udziału w badaniu i odnośnikiem kierującym do elektronicznej wersji ankiety. Nie jest znana dokładna liczba osób, które odebrały i odczytały wiadomość oraz otworzyły stronę z ankietą. Zwrotnie odpowiedziały 64 osoby. W związku z brakami danych odrzucono dwie odpowiedzi i w ostatecznej analizie uwzględniono odpowiedzi 62 osób. Spośród uczestników 34 osoby studiowały na II roku (10 mężczyzn i 24 kobiety), a 28 osób było studentami roku III (3 mężczyzn i 25 kobiet). 


\section{Materiał}

Elektroniczna wersja ankiety przygotowana została w pakiecie narzędzi Google. Ankieta podzielona była na pięć sekcji obejmujących łącznie sześć pytań zamkniętych i trzy pytania otwarte. W pierwszej sekcji zawarte zostały informacje wstępne dotyczące celu badania, dobrowolności udziału w badaniu oraz pełnej anonimowości uczestników. Przejście do kolejnych sekcji możliwe było po wypełnieniu metryczki z pytaniami o płeć (od wyboru płci uzależniona była gramatyczna forma poleceń w dalszych sekcjach) oraz rok i tryb studiów.

W sekcji drugiej znajdowały się trzy pytania dotyczące dydaktyki psychologii behawioralnej:

1. Jak oceniasz poziom swojej wiedzy na temat paradygmatu psychologii behawioralnej? (ocena od „Bardzo niski” do „Bardzo wysoki”);

2. Jak oceniasz poziom wiedzy dostarczanej na studiach psychologicznych na temat psychologi behawioralnej? (ocena od „Niewystarczający” do „Kompletny”);

3. Czy chciałabyś poszerzyć swoją wiedzę na temat psychologii behawioralnej? (ocena od „Zdecydowanie NIE” do „Zdecydowanie TAK”).

Do zapisania odpowiedzi służyła pięciostopniowa skala (1-5). Skrajne punkty skali zaopatrzono w etykiety wyrazowe, pomocne w dokonaniu oceny (podane powyżej w nawiasach przy każdym z pytań).

Sekcja trzecia rozpoczynała się informacją: „W wielu ośrodkach akademickich podczas kursu psychologii behawioralnej studenci wykonują eksperymenty na zwierzętach laboratoryjnych w celu zrozumienia praw rządzących zachowaniem. Obejrzyj krótki film prezentujący taki eksperyment wykonywany w tzw. Klatce Skinnera i odpowiedz na pytania poniżej”. Dalej prezentowany był 24-sekundowy film przedstawiający szczura w klatce eksperymentalnej oraz wyświetlane było pytanie dotyczące chęci udziału w zajęciach, na których przeprowadza się eksperymenty z udziałem zwierząt. Do zapisania odpowiedzi służyła pięciostopniowa skala (1-5, etykiety pomocnicze: „Zdecydowanie NIE” i „Zdecydowanie TAK”) oraz pole tekstowe do zapisania krótkiego uzasadnienia odpowiedzi.

Analogicznie skonstruowana została sekcja czwarta. Rozpoczynała ją informacja: „Na niektórych uczelniach podczas kursu psychologii behawioralnej zamiast żywych zwierząt wykorzystuje się programy komputerowe symulujące zachowanie zwierząt. Obejrzyj krótki film prezentujący eksperyment wykonywany w wirtualnej Klatce Skinnera i odpowiedz na pytania poniżej”, pod którą znajdowało się okno z 24-sekundowym filmem prezentującym pracę w programie Sniffy. Pytanie zamykające sekcję dotyczyło chęci udziału w zajęciach, na których przeprowadza się symulacje eksperymentów na wirtualnych zwierzętach. 
Ostatnia sekcja zawierała pytanie, „Gdybyś mógł/mogła wybrać między eksperymentami na żywym szczurze a symulacjami eksperymentu na szczurze wirtualnym, to którą opcje byś wybrał(a)?”. Wybór spośród dwóch możliwych opcji również należało uzasadnić, po czym można było przesłać wszystkie odpowiedzi.

\section{Procedura}

Poszczególne sekcje ankiety wyświetlane były jako kolejne etapy badania. Przejście do kolejnego etapu następowało po udzieleniu odpowiedzi na wszystkie pytania w danej sekcji. Odpowiedzi udzielano poprzez wybór opcji z listy (np. płeć), zaznaczanie punktu 1-5 na skali, wpisanie odpowiedzi w polu tekstowym. W związku z tym, że osoby badane samodzielnie uruchamiały wyświetlanie filmów prezentujących żywego i wirtualnego szczura, pod każdym filmem zawarto pytanie kontrolne, wymagające potwierdzenia obejrzenia danego filmu. Badanie kończyło się powodzeniem w momencie, kiedy wybrany został przycisk „Prześlij”. Podczas pracy z ankietą można było powrócić do wcześniejszych sekcji i zmienić odpowiedzi. Po zakończeniu pracy i przesłaniu odpowiedzi, powrót do ankiety nie był możliwy.

\section{Wyniki}

Odpowiedzi studentów na pytania dotyczące zdobywanej na studiach wiedzy z zakresu psychologii behawioralnej wskazują, że jest ona przez nich oceniana na poziomie średnim. Tym samym pytanie o chęć poszerzenia tej wiedzy spotkało się w większości z pozytywną odpowiedzią studentów. Odpowiedzi na te pytania prezentuje tabela 1.

Tabela 1. Odpowiedzi na pytania dotyczące wiedzy na temat psychologii behawioralnej

\begin{tabular}{lcccccc}
\hline & \multicolumn{2}{c}{$\begin{array}{c}\text { Ocena poziomu } \\
\text { swojej wlasnej wiedzy }\end{array}$} & $\begin{array}{c}\text { Ocena poziomu wiedzy } \\
\text { dostarczanej } \\
\text { na studiach }\end{array}$ & \multicolumn{2}{c}{$\begin{array}{c}\text { Chęć poszerzenia } \\
\text { swojej własnej wiedzy }\end{array}$} \\
\hline $\begin{array}{l}\text { Odpowiedzi } \\
\text { na skali pkt. }\end{array}$ & $\mathbf{N}$ & $\mathbf{\%}$ & $\mathbf{N}$ & $\mathbf{\%}$ & $\mathbf{N}$ & $\%$ \\
\hline 1 & 0 & 0 & 6 & 9,7 & 1 & 1,6 \\
\hline 2 & 9 & 14,5 & 9 & 14,5 & 10 & 16,1 \\
\hline 3 & 37 & 59,7 & 22 & 35,5 & 10 & 16,1 \\
\hline 4 & 15 & 24,2 & 23 & 37,1 & 21 & 33,9 \\
\hline 5 & 1 & 1,6 & 2 & 3,2 & 20 & 32,3 \\
\hline
\end{tabular}

Na rysunku 1 przedstawiono procentowe zestawienie odpowiedzi na pytania dotyczące zainteresowania studentów udziałem w zajęciach polegających na przeprowadzaniu eksperymentów na żywych zwierzętach lub na ich wirtualnych 


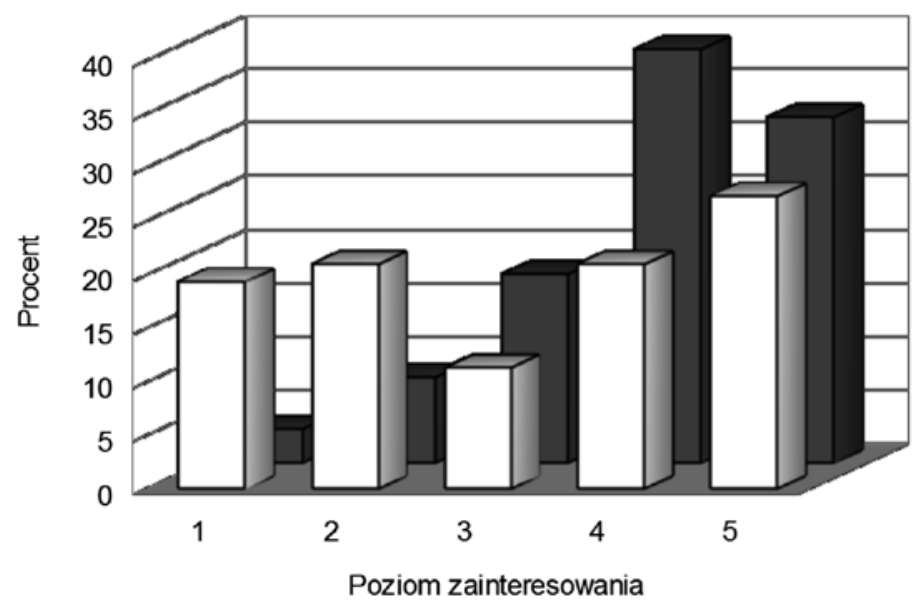

$\square$ Żywe zwierzęta

Wirtualne zwierzęta

Rysunek 1. Zainteresowanie eksperymentami z żywymi i wirtualnym zwierzętami

odpowiednikach. Porównanie odpowiedzi wskazuje na większe zainteresowanie studentów symulacjami eksperymentów (Mrang = 27,68) niż ich rzeczywistym wykonywaniem z udziałem żywych zwierząt (Mrang = 18,71). Analiza testem znaków rangowych Wilcoxona wykazała, że różnica ta jest istotna statystycznie $\mathrm{Z}=2,805 ; p<0,01$.

Pisemne odpowiedzi uzasadniające dokonane wybory w większości poruszały więcej niż jedną kwestię, co utrudnia ich jednoznaczną klasyfikację. Z tego powodu postanowiono zliczyć odpowiedzi, w których pojawiają się argumenty dotyczące wartości edukacyjnej zajęć, ich atrakcyjności oraz kwestii etycznych. W odniesieniu do zajęć wykorzystujących żywe zwierzęta najczęściej (12 odpowiedzi) podkreślana była ich przydatność w zdobywaniu wiedzy, ze względu na praktyczny (poglądowy, doświadczalny) charakter. Atrakcyjność takich zajęć podkreślało 8 osób, oceniając je jako ciekawe i interesujące. Jednocześnie 9 osób deklarowało chęć udziału w zajęciach tylko pod warunkiem, że zwierzętom nie będzie działa się krzywda, a 24 osoby uznały doświadczenia na zwierzętach za nieetyczne i niehumanitarne, czym motywowało swój niechętny lub obojętny stosunek do zajęć.

Kwestie etyczne są również ważne w deklaracjach zainteresowania zajęciami, na których wykonuje się symulacje eksperymentów. W uzasadnieniu wyboru takich zajęć większość osób (24 odpowiedzi) wskazała na ich etyczny charakter. Część respondentów uważała również, że zajęcia takie mogą być interesujące (17 odpowiedzi) i pożyteczne (10 odpowiedzi) ze względu na swój praktyczny 
i poglądowy charakter. Jednocześnie 12 osób wyraziło wątpliwość w wiarygodność symulacji, która nie oddaje rzeczywistego (naturalnego, spontanicznego) zachowania zwierzęcia.

W odpowiedzi na pytanie o wybór pomiędzy zajęciami z żywym szczurem a jego wirtualnym odpowiednikiem, 30 osób wybrałoby pierwszą opcję, podczas gdy 32 osoby wolałyby pracę na symulatorze. Występuje tu również większa polaryzacja odpowiedzi uzasadniających te wybory. Osoby wybierające eksperymenty in vivo motywowały swoją decyzję realizmem i autentycznością zachowania żywego szczura w przeciwieństwie do sztuczności symulacji (18 odpowiedzi), większą atrakcyjnością takich zajęć (8 odpowiedzi) oraz zamiłowaniem do zwierząt (2 odpowiedzi). Dwie odpowiedzi nie zostały uzasadnione. Wybór wirtualnego szczura podyktowany jest natomiast kwestiami etycznymi (26 odpowiedzi), niechęcią do pracy ze zwierzętami (3 odpowiedzi), względami ekonomicznymi (2 odpowiedzi) oraz atrakcyjnością tej formy nauki (1 odpowiedź).

Dodatkowo uwzględnienie czynnika płci jako zmiennej niezależnej pokazuje, że wśród mężczyzn przeważa wyraźna preferencja dla wyboru eksperymentów na żywych szczurach (77\%), natomiast większość kobiet wybrałaby wirtualne zwierzę (59\%). Wykonanie testu chi kwadrat wykazuje, że ta zależność jest istotna statystycznie $\mathrm{X} 2(1)=5,363 ; p<0,05$, przy umiarkowanym związku między płcią studentów a wyborem rodzaju zajęć, $\varphi=0,29 ; p<0,05$. Procentowy rozkład odpowiedzi prezentuje rysunek 2 .

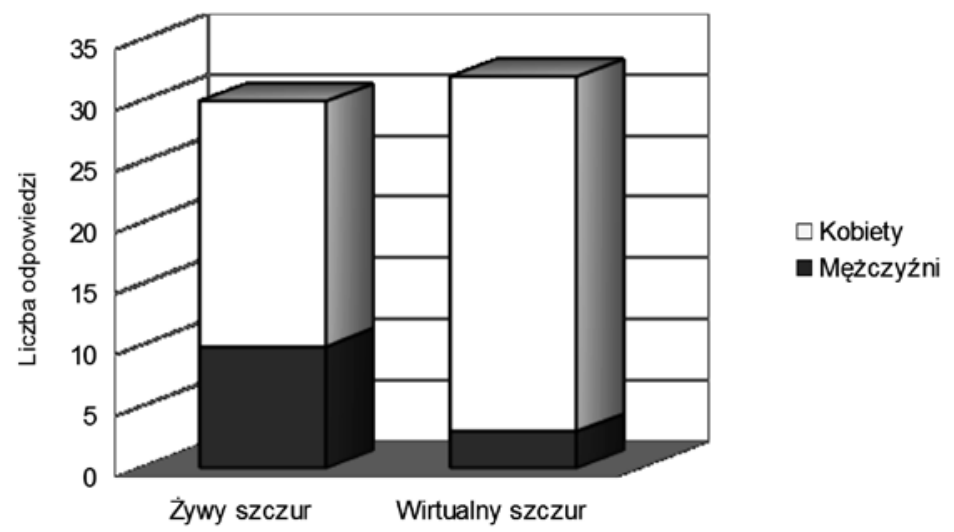

Rysunek 2. Zestawienie wyboru żywego lub wirtualnego szczura z uwzględnieniem płci rspondentów 


\section{Ankieta 2: Ocena wirtualnego laboratorium}

Celem przeprowadzonego badania było sprawdzenie, jak pracę z programem „Sniffy, the virtual rat” oceniają studenci, którzy mieli możliwość wykonywać w nim symulacje eksperymentów. Ponadto ważne było ustalenie, czy wątpliwości respondentów ankiety 1 dotyczące wiarygodności programu w odzwierciedlaniu zachowania szczura znajdą swoje potwierdzenie.

\section{METODA}

\section{Uczestnicy}

Ankieta 2 została przeprowadzona wśród studentów IV roku, którzy w semestrze letnim roku akademickiego 2015/2016 uczestniczyli w proseminarium „Psychologia behawioralna: od analizy do modyfikacji zachowania”. Studenci korzystali z programu Sniffy w pracowni komputerowej podczas zajęć poświęconych warunkowaniu klasycznemu i sprawczemu, a także mieli możliwość pracy z programem po zajęciach w celu wykonania fakultatywnych prac domowych. Po zakończeniu kursu do uczestników zajęć (25 osób) została wysłana elektroniczna wiadomość na studencką skrzynkę pocztową z odnośnikiem do ankiety i prośbą o jej wypełnienie. W związku z tym, że nie wszyscy studenci byli obecni na zajęciach w pracowni komputerowej, zwrotnie odpowiedzi na pytania dotyczące pracy z programem Sniffy udzieliły 22 osoby (17 kobiet i 5 mężczyzn).

\section{Materiał}

Elektroniczna wersja ankiety przygotowana została w pakiecie narzędzi Google. Ankieta składała się z dwóch zestawów pytań zamkniętych, dwóch pytań otwartych oraz metryczki. Treść pytań była inspirowana wynikami badania Elcoro i Trundle (2013). Pierwszy zestaw pytań obejmował sześć stwierdzeń dotyczących doświadczeń studentów w pracy z programem Sniffy. Odpowiedzi zapisywane były jako wybór jednej z czterech opcji: „Zdecydowanie się zgadzam”, „Raczej się zgadzam”, „Raczej się nie zgadzam” i „Zdecydowanie się nie zgadzam”. Drugi zestaw pytań obejmował dziewięć stwierdzeń dotyczących oceny programu Sniffy i możliwości jego zastosowania w dydaktyce. Pytania otwarte dotyczyły dostrzeganych przez studentów wad i zalet programu Sniffy. W metryczce zawarto pytanie o płeć i tryb studiów. 


\section{Procedura}

Odpowiedzi na pytania udzielano poprzez wybór jednej z czterech opcji (od „Zdecydowanie się zgadzam” do „Zdecydowanie się nie zgadzam”) oraz wpisanie odpowiedzi w polu tekstowym. Badanie kończyło się powodzeniem w momencie, kiedy po wypełnieniu metryczki wybrany został przycisk „Prześlij”. Podczas pracy z ankietą można było powrócić do wcześniejszych sekcji i zmienić odpowiedzi. Po zakończeniu pracy i przesłaniu odpowiedzi, powrót do ankiety nie był możliwy.

\section{Wyniki}

Odpowiedzi studentów wskazują na pozytywne doświadczenia wyniesione z zajęć w wirtualnym laboratorium. Dla wszystkich praca z programem Sniffy była interesująca, a większość (ponad 90\%) uznała ją za „dobrą zabawę”, pomocną w zrozumieniu materiału z zajęć i mającą przełożenie praktyczne. Dla większości osób obsługa programu i analiza wyników nie stanowiła też znacznej trudności. Zestawienie odpowiedzi prezentuje Tabela 2.

Tabela 2. Zestawienie odpowiedzi dotyczących doświadczeń w pracy z programem Sniffy

\begin{tabular}{|c|c|c|c|c|c|c|c|c|}
\hline \multirow{3}{*}{ Twierdzenia } & \multicolumn{8}{|c|}{ Odpowiedzi } \\
\hline & \multicolumn{2}{|c|}{$\begin{array}{l}\text { Zdecydowanie } \\
\text { się zgadzam }\end{array}$} & \multicolumn{2}{|c|}{$\begin{array}{l}\text { Raczej się } \\
\text { zgadzam }\end{array}$} & \multicolumn{2}{|c|}{$\begin{array}{c}\text { Raczej się } \\
\text { nie zgadzam }\end{array}$} & \multicolumn{2}{|c|}{$\begin{array}{l}\text { Zdecydowanie } \\
\text { się nie zgadzam }\end{array}$} \\
\hline & $\mathrm{N}$ & $\%$ & $\mathrm{~N}$ & $\%$ & $\mathrm{~N}$ & $\%$ & $\mathrm{~N}$ & $\%$ \\
\hline $\begin{array}{l}\text { Praca z programem była dla } \\
\text { mnie interesująca. }\end{array}$ & 10 & 45,5 & 12 & 54,5 & 0 & 0 & 0 & 0 \\
\hline $\begin{array}{l}\text { Praca z programem była dla } \\
\text { mnie „dobrą zabawą”. }\end{array}$ & 11 & 50 & 9 & 40,9 & 2 & 9,1 & 0 & 0 \\
\hline $\begin{array}{l}\text { Obsługa programu } \\
\text { sprawiała mi trudność. }\end{array}$ & 1 & 4,5 & 2 & 9,1 & 12 & 54,5 & 7 & 31,8 \\
\hline $\begin{array}{l}\text { Analiza wyników ekspe- } \\
\text { rymentów sprawiała mi } \\
\text { trudność. }\end{array}$ & 1 & 4,5 & 5 & 22,7 & 14 & 63,6 & 2 & 9,1 \\
\hline $\begin{array}{l}\text { Praca z programem } \\
\text { pomogła mi zrozumieć } \\
\text { materiał z zajęć. }\end{array}$ & 12 & 54,5 & 9 & 40,9 & 1 & 4,5 & 0 & 0 \\
\hline $\begin{array}{l}\text { Rezultaty wykonanych } \\
\text { eksperymentów mają } \\
\text { przełożenie praktyczne. }\end{array}$ & 11 & 50 & 9 & 40,9 & 2 & 9,1 & 0 & 0 \\
\hline
\end{tabular}

Podobnie pozytywnie oceniany jest przez studentów sam program. Większość osób uznała, że animacja jest realistyczna (73\%), a program adekwatnie reprezentuje zachowanie żywego szczura (86\%), wiarygodnie przedstawiając mechanizmy 
uczenia się (91\%). Choć prawie połowa studentów (45\%) ocenia pracę z żywym szczurem jako bardziej interesującą, to jednak większość uważa, że symulacja może zastąpić realne zwierzę (77\%), a program Sniffy powinien być obowiązkowo używany na zajęciach (91\%). W ocenie studentów symulacja eksperymentów jest bardziej etyczna niż eksperymenty in vivo (95\%) i wszyscy są zgodni, że praca z wirtualnym szczurem jest dobrym rozwiązaniem dla osób, które boją się żywych szczurów. Zestawienie odpowiedzi prezentuje tabela 3.

Tabela 3. Zestawienie odpowiedzi dotyczących oceny programu Sniffy

\begin{tabular}{|c|c|c|c|c|c|c|c|c|}
\hline \multirow[t]{3}{*}{ Twierdzenia } & \multicolumn{8}{|c|}{ Odpowiedzi } \\
\hline & \multicolumn{2}{|c|}{$\begin{array}{l}\text { Zdecydowanie } \\
\text { się zgadzam }\end{array}$} & \multicolumn{2}{|c|}{$\begin{array}{l}\text { Raczej się } \\
\text { zgadzam }\end{array}$} & \multicolumn{2}{|c|}{$\begin{array}{c}\text { Raczej się } \\
\text { nie zgadzam }\end{array}$} & \multicolumn{2}{|c|}{$\begin{array}{l}\text { Zdecydowanie } \\
\text { się nie zgadzam }\end{array}$} \\
\hline & $\mathbf{N}$ & $\%$ & $\mathbf{N}$ & $\%$ & $\mathbf{N}$ & $\%$ & $\mathbf{N}$ & $\%$ \\
\hline $\begin{array}{l}\text { Animacja zachowania wirtual- } \\
\text { nego szczura jest realistyczna. }\end{array}$ & 2 & 9,1 & 14 & 63,6 & 5 & 22,7 & 1 & 4,5 \\
\hline $\begin{array}{l}\text { Program adekwatnie reprezen- } \\
\text { tuje reakcje żywego szczura. }\end{array}$ & 1 & 4,5 & 18 & 81,8 & 2 & 9,1 & 1 & 4,5 \\
\hline $\begin{array}{l}\text { Symulacja wiarygodnie przed- } \\
\text { stawia mechanizmy uczenia się } \\
\text { na drodze war. klasycznego. }\end{array}$ & 9 & 40,9 & 11 & 50 & 2 & 9,1 & 0 & 0 \\
\hline $\begin{array}{l}\text { Symulacja wiarygodnie przed- } \\
\text { stawia mechanizmy uczenia się } \\
\text { na drodze war. sprawczego. }\end{array}$ & 8 & 36,4 & 12 & 54,5 & 2 & 9,1 & 0 & 0 \\
\hline $\begin{array}{l}\text { Praca z tym programem } \\
\text { może zastąpić pracę z żywym } \\
\text { szczurem. }\end{array}$ & 7 & 31,8 & 10 & 45,5 & 5 & 22,7 & 0 & 0 \\
\hline $\begin{array}{l}\text { Ten program powinien być wy- } \\
\text { korzystywany obowiązkowo } \\
\text { na zajęciach z psychologii. }\end{array}$ & 8 & 36,4 & 12 & 54,5 & 2 & 9,1 & 0 & 0 \\
\hline $\begin{array}{l}\text { Praca z żywym szczurem jest } \\
\text { bardziej interesująca niż praca } \\
\text { z wirtualnym szczurem. }\end{array}$ & 5 & 22,7 & 5 & 22,7 & 6 & 27,3 & 6 & 27,3 \\
\hline $\begin{array}{l}\text { Praca z wirtualnym szczurem } \\
\text { jest dobrym rozwiązaniem dla } \\
\text { osób, które boją się żywych } \\
\text { szczurów. }\end{array}$ & 19 & 86,4 & 3 & 13,6 & 0 & 0 & 0 & 0 \\
\hline $\begin{array}{l}\text { Praca z wirtualnym szczurem } \\
\text { jest bardziej etyczna niż praca } \\
\text { z żywym szczurem. }\end{array}$ & 20 & 90,9 & 1 & 4,5 & 1 & 4,5 & 0 & 0 \\
\hline
\end{tabular}

Wśród wskazywanych przez studentów zalet programu najczęściej podkreślane były względy etyczne (11 odpowiedzi) oraz praktyczne, związane z lepszym przyswojeniem wiedzy dzięki obserwacji warunkowania w działaniu (10 odpowiedzi). Ponadto doceniane są kwestie ekonomiczne (niski koszt przy dużej dostępności 
- 2 odpowiedzi), efektywność symulacji (wygoda i szybkość - 3 odpowiedzi) oraz atrakcyjność pracy z programem (5 odpowiedzi). Wśród wad - poza kwestiami dotyczącymi organizacji zajęć - najczęstsze uwagi dotyczą tego, na ile symulacja oddaje rzeczywistość (7 odpowiedzi). Ponadto jako wada wskazywany jest brak polskiej wersji językowej programu (4 odpowiedzi) oraz „śmiertelność” wirtualnego szczura (2 odpowiedzi).

\section{DYSKUSJA}

Uzyskane na początku pierwszej ankiety odpowiedzi sugerują, że wśród studentów psychologii istnieje zapotrzebowanie na wiedzę z zakresu psychologii behawioralnej. W związku z tym, że w Polsce wykonywanie przez studentów eksperymentów nad uczeniem się zwierząt w celach dydaktycznych nie jest powszechną praktyką, zasadne jest pytanie o możliwość wykorzystania programu „Sniffy, virtual rat” jako alternatywnej pomocy edukacyjnej. Choć celem badania nie było wykazanie wyższości symulacji nad eksperymentami in vivo, większe zainteresowanie wśród studentów wzbudziła propozycja zajęć z wykorzystaniem wirtualnego zwierzęcia. Stoją za tym przede wszystkim kwestie etyczne, a także uznanie, że taka forma zajęć może być ciekawa i przydatna w przyswajaniu wiedzy. Największe wątpliwości dotyczą tego, czy symulacja jest w stanie wiarygodnie odzwierciedlić zachowanie żywego zwierzęcia. Z powyższych względów, w momencie konieczności dokonania wyboru: eksperyment czy symulacja, głosy studentów rozkładają się po równo, przy czym mężczyźni bardziej preferowaliby pracę z żywym szczurem, a kobiety - z wirtualnym. Tendencje te są zgodne z wynikami badania Plousa (1995), w którym kobiety wyrażały mniejsze poparcie dla badań z wykorzystaniem żywych zwierząt niż mężczyźni. Biorąc pod uwagę większy odsetek kobiet na studiach psychologicznych, można przyjąć, że zajęcia z użyciem programu Sniffy mogłyby cieszyć się dużym zainteresowaniem, nawet gdyby w ofercie dydaktycznej przewidziano eksperymenty na żywych zwierzętach.

Dodatkowo za wykorzystaniem wirtualnego laboratorium przemawiają głosy studentów, którzy mieli możliwość korzystać z programu Sniffy. W większości bardzo dobrze oceniają oni pracę w tym programie, dostrzegając jego walory edukacyjne. Podobnie jak w odpowiedziach poprzedniej grupy wyraźne jest napięcie pomiędzy etycznością symulacji a realnością eksperymentów in vivo. Jednocześnie doświadczenie pracy z wirtualnym szczurem powoduje, że wątpliwości dotyczące wiarygodności symulacji tracą na znaczeniu, a większość osób pozytywnie ocenia poziom symulacji. Dostrzegane przez studentów zalety wykorzystania programu 
na zajęciach podkreślają jego wartość jako atrakcyjnej pomocy dydaktycznej, a wskazywane wady nie stanowią przeszkody w efektywnym wykorzystaniu programu do nauki praw warunkowania. W związku z tym, że ponad 90\% studentów korzystających z programu Sniffy rekomenduje jego obligatoryjne użycie na zajęciach, warto zastanowić się nad jego wykorzystaniem nie tylko w dydaktyce psychologii behawioralnej, ale również w nauczaniu innych przedmiotów, które w swoim programie omawiają mechanizmy uczenia się i odwołują do eksperymentów nad warunkowaniem (por. Brzezińska, Brzeziński, Eliasz, 2000).

\section{Literatura:}

Alloway, T., Wilson, G., Graham, J. (2009). Sniffy the virtual rat - Pro Version 3.0. Belmont, CA: Wadsworth Cengage Learning.

Bąbel, P. (2008). Warunkowanie klasyczne jako mechanizm działania placebo. W: P. Bąbel, P. Ostaszewski (red.), Współczesna psychologia behawioralna. Wybrane zagadnienia (s. 205-237). Kraków: Wydawnictwo Uniwersytetu Jagiellońskiego.

Bąbel, P., Ostaszewski, P. (2008). Wprowadzenie do psychologii behawioralnej. W: P. Bąbel, P. Ostaszewski (red.), Współczesna psychologia behawioralna. Wybrane zagadnienia (s. 7-21). Kraków: Wydawnictwo Uniwersytetu Jagiellońskiego.

Bąbel, P., Suchowierska-Stephany, M., Ostaszewski, P. (2016). Analiza zachowania. Vademecum. Sopot: Gdańskie Wydawnictwo Psychologiczne.

Brzezińska, A., Brzeziński, J.I. Eliasz, A. (red.), (2000). Standardy kształcenia psychologów. Programy kształcenia w bloku podstawowym. Poznań: Wydawnictwo Naukowe UAM.

Cunningham, F. (2003). Animal use, student choice, and nonanimal alternatives at „America's best” undergraduate colleges. Teaching of Psychology, 30 (4), s. 288-296.

Domachowski, W. (2007). Przewodnik po psychologii społecznej. Warszawa: Wydawnictwo Naukowe PWN.

Domjan, M.P. (2015). The Principles of Learning and Behavior (6th ed.). Belmont, CA: Wadsworth Cengage Learning.

Domjan, M., Purdy, J.E. (1995). Animal research in psychology more than meets the eye of the general psychology student. American Psychologist, 50, s. 496-503.

Elcoro, M., Trundle, M. (2013). Student Preferences for Live Versus Virtual Rats in a Learning Course. International Journal for the Scholarship of Teaching and Learning, 7 (1), s. 1-13.

Frick, F.C., Keller, F.S., Schoenfeld, W.N. (1948). Apparatus designed for introductory psychology at Columbia College. The American Journal of Psychology, 61 (3), s. 409-414.

Godcharles, Ch., Stebbins, W.C. (1962). A student laboratory for operant conditioning. Journal of The Experimental Analysis of Behavior, 5 (4), s. 457-459.

Graf, S. (1995). Three nice labs, no real rats: A review of three operant laboratory simulations. The Behavior Analyst, 18 (1), s. 301-306. 
Hergenhahn, B.R. (2005). An Introduction to the History of Psychology. Wadsworth: Cengage Learning.

Jakubow, J. (2007). Review of the book „Sniffy the virtual rat pro version 2.0”. Journal of the Experimental Analysis of Behavior, 87, s. 317-323

Karp, H.J. (1995). Rat lab for fun and profit. The Behavior Analyst, 18, s. 147-154.

Murphy, E.S., Madigan, R.J. (2011). Teaching Classical and Operant Conditioning in a Laboratory-Based Course: Eight Effective Experiments. Journal of Behavioral and Neuroscience Research, 9 (2), s. 120-137.

Nęcka, E., Orzechowski, J., Szymura, B. (2006). Psychologia poznawcza. Warszawa: Wydawnictwo Naukowe PWN.

Paw, Ł. (2010). Recenzja książki „Współczesna psychologia behawioralna: wybrane zagadnienia”. Przegląd Psychologiczny, 53 (1), s. 121-123.

Plous, S. (1996). Attitudes toward the use of animals in psychological research and education: Results from a national survey of psychologists. American Psychologist, 51, s. $1167-1180$.

Skinner, B.F. (2000/1963). Pół wieku behawioryzmu. W: J. Siuta, K. Krzyżewski (red.), Behawioryzm i psychologia świadomości (s. 87-105). Kraków: Wydawnictwo UJ.

Venneman, S.S., Knowles, L.R. (2005). Sniffing Out Efficacy: Sniffy Lite, a Virtual Animal Lab. Teaching of Psychology. 32 (1), s. 66-68.

Watson, J.B. (1916). The Place of the Conditioned Reflex in Psychology. Psychological Review, 23, s. 89-116.

Watson, J.B. (1990/1925). Behawioryzm oraz psychologia, jak ją widzi behawiorysta. Warszawa: PWN. 